\title{
Intercultural and Religious Sensitivity among Young Indonesian Interfaith Groups
}

\author{
Jamaludin Hadi Kusuma ${ }^{1, *}$ and Sulistiyono Susilo ${ }^{2, *}$ \\ 1 Faculty of Islamic Theology, Universitas Islam Negeri Sunan Kalijaga, Yogyakarta 55281, Indonesia \\ 2 Institute of Social Sciences and Cultural Studies, Yogyakarta 55233, Indonesia \\ * Correspondence: 17105030100@student.uin-suka.ac.id (J.H.K.); sulistiyonosusilo@gmail.com (S.S.)
}

Received: 6 November 2019; Accepted: 27 December 2019; Published: 2 January 2020

\begin{abstract}
Increasing tension and conflict in interfaith relations throughout the world has encouraged interfaith dialogue introduced by various well-known figures and world organizations to facilitate intercultural and interreligious understanding and tolerance. Interreligious dialogue now involves more youth participation, as they are more likely to guarantee the sustainability of civic values, intercultural relations, and social advocacy. This article analyzes the sensitivity of young interfaith activists in two civil organizations in Yogyakarta, Indonesia. Psychometric measures using the Intercultural and Religious Sensitivity Scale Questionnaire (IRSSQ) were analyzed to test three research questions: (1) Are there differences in intercultural and religious sensitivity between Muslim and Christian activists? (2) Are there differences in intercultural and religious sensitivity between female and male students? (3) Are there differences in sensitivity between the two organizations? The results suggest that inherent multiculturalism in Indonesian culture provides a strong foundation for interfaith activists in responding to cultural and religious differences. The results of this study theoretically confirm previous studies to promote intercultural education and interfaith encounters to overcome the threat of ethnocentrism. This study also encourages the strengthening of comprehension, competence and communication in intercultural sensitivity in young interfaith activists in Indonesia.
\end{abstract}

Keywords: interreligious sensitivity; intercultural and interfaith dialogue; social advocacy; youth activists; IRSSQ

\section{Introduction}

In the perspective of civil society, society is an independent organ, and the state is formed as a horizontal contract between groups to help them achieve the goal of living together (Putnam 1994). The introduction of modern nation-state systems, with a variety of rigid rules and boundaries, has forced the communities of each independent group to become unified and become homogeneous. As a result, the independence becomes blurred, and at the same time, the group's character still persists in each of them. Conflict resolution, which in the past can be resolved by customary agreements or local mediation based on consensus, equality, and mutual respect, becomes ineffectively abandoned due to the rigidity of existing legal regulations (Shehada 2009). In this context, the role of civil society is needed to participate in advocating for the interests of the lower classes, restoring harmonious relations and advocating for various interests of the community in the modern state system (Paffenholz 2010).

As a multicultural nation, tension and social violence based on religion and ethnicity have repeatedly occurred throughout Indonesian history (Bertrand 2002; Al Qurtuby 2015; Schulze 2017). The awareness of the importance of civil society in Indonesia began to grow in the early 1980s, along with the strengthening of the repressive grip of the New Order massively supported by the military (Hefner 1993; Aspinall 2004). The growth of civil organizations received many threats from the government at the time, in connection with the fear of opposing the government. The increasingly 
intense military involvement in politics made several public figures and religious organization leaders such as Nurcholis Madjid (a.k.a Cak Nur, 1939-2005), Dawam Rahardjo (1942-2018), Abdurrahman Wahid (a.k.a Gus Dur, 1940-2009) and Amien Rais (b. 1944), actively participated in the process of forming civil society by loudly voicing the importance of freedom of opinion, democracy and social advocacy for anti-discrimination (Azra 2007; Riddell 2002; Kadir 1999; Bakti 2005). This political background for the birth of civil societies in Indonesia remains a special basis in the following period, due to the massive legacy of the New Order's policy which continues to color the relationship between religion and social vulnerability in Indonesia. Civil society organizations nowadays are increasingly developing with various forms and orientations, some of which actively advocate for legal and human rights cases such as Lembaga Bantuan Hukum (LBH) Jakarta, Komisi Untuk Orang Hilang Dan Korban Tindak Kekerasan (KontraS), Imparsial; and others focusing on social issues, such as LBH Apik and Fahmina Institute on gender issues and Fitra and Transparency International Indonesia (TII) focusing on corruption. However, it is worth noting that the focus of the contemporary civil society movement also has its own unique side, due to the growing movement of extremism, and the decline in the magnitude and resonance of civil society (Hefner 2019; Diprose et al. 2019; Hefner 2018; Power 2018; Hamayotsu 2013). Although the role of civil society still reverberates in the early days after the collapse of the Suharto regime in 1998, social support is shrinking due to the loss of orientation due to the death of several prominent figures, such as Gus Dur, Cak Nur, and Dawam Rahardjo, and practical involvement of civil society leaders in politics. As a result, the focal point of civil society on the issue of interfaith relations in Indonesia became less visible, although some groups still actively voice the importance of this kind of social advocacy in young groups (Jones et al. 2015; Sarapung and Ven 2016; Sunarko Ofm 2016). The important role of social advocacy is carried out with various trainings and cadres for certain missions involving interfaith relations (Jonathan et al. 2018).

In the midst of the strengthening of religious extremism, interfaith groups, as the forefront of the interfaith movement, should have capable standards and an inclusive view in all circles, allowing them not to be exclusive from any group, and should be seen as credible actors in peace building (Liebmann 2017; Michaelides 2009; Larson and Shady 2009). Interfaith movements for the purpose of providing a transformative dialogue process must begin with mutual affection among facilitators. For this reason, empirical analysis is needed to examine the intercultural sensitivity of activists involved in interfaith dialogue. Cultural sensitivity refers to a set of skills that enable activists to understand and learn about people with different cultural backgrounds. This study specifically underlines and empirically examines interfaith and cultural sensitivity among young Indonesian activists. Empirical testing was carried out on activists in two interfaith organizations, the Young Interfaith Peacemaker Community (YIPC) and DIAN/Interfidei based in Yogyakarta, Indonesia. In general, both organizations adopt inclusive membership regardless of religion, gender and ethnic background. The nature of inclusiveness in these two organizations is deemed appropriate for verifying the degree of interreligious sensitivity. More specifically, the purpose of this study is to analyze differences in intercultural and religious sensitivity between Muslim and Christian activists, differences in intercultural and religious sensitivity between female and male students, and differences in sensitivity between the two organizations. The test was carried out using the main method of IRSSQ which was developed from Bennett (1993) and modified according to the research locus and subject characteristics. The findings reveal the importance of instilling the values of tolerance and pluralism in interfaith education. The findings recommend the importance of pluralism and value comprehension among activists involved in interfaith education to ensure interfaith relations according to the needs and challenges at the local level. The novelty of this study lies in testing the sensitivity among young interfaith activists in Indonesia with the empirical method through the IRSSQ. This kind of focus has not been emphasized in previous studies, which mostly focus on testing the IRSSQ in different sample characteristics (Tamam 2010; Dong et al. 2008; Demircioglu and Cakir 2016; Petrović et al. 2015; Wu 2015; Holm et al. 2009) and emphasizes less on the analysis of whether interfaith activists themselves have plural and inclusive understandings. Previous studies arguably hold a tendency to separate between interfaith education and sensitivity 
testing among activists because of the assumption that education and activism are inherently integrated. It is worth noting that in this study, "interfaith" and "interreligious" were synonymous, and culture in this study refers to differences among religions. In addition, civil society is defined as tolerant, pluralist and egalitarian civil organizations (see Carothers 1999).

\section{Literature Review}

\subsection{Civil Society, Islamic Moderatism, and Social Capital}

Civil society in Indonesia first grew along with the strengthening of state intervention in private life during Suharto's New Order (1966-1998). At this time, state intervention encompasses several private aspects such as the establishment of state-recognized religions, the obligation to include religion on identity cards, and marginalizing the position of indigenous religions (Hefner 2013; Sezgin and Künkler 2014). The New Order mainly utilized the Pancasila national ideology to carry out its political agendas. Pancasila was basically formed as a national ideological philosophy by Sukarno (1901-1970), who had the character of national social insight to unite social, cultural and religious diversity in a new country which was later called Indonesia; this ideology however, in Suharto's hand, was radically transformed into an ideology with political overtones (Ward 2010). Pancasila, at the beginning of its formation, is the national value, which reflects the richness of history, culture, beliefs and social diversity accommodated in the five precepts, namely, divinity, humanity, national unity, democracy and social justice. Philosophically, Pancasila is rooted in social values that describe the views, character and foundations of Indonesian nationality which are oriented towards diversity, cooperation, collectivity and social harmony (for a more detailed discussion of Indonesian social values see, Geertz 1976; Mulder 1970; for a discussion of the historical aspects, rationality, and actuality of Pancasila see, Latif 2011). This ideology is a manifestation of achievements which have succeeded in uniting a socially and culturally diverse nation. Sukarno also used Pancasila as a base of resistance to imperialism and encouraged Third World countries not to get involved in the Cold War through the Non-Aligned Organization in 1961 (Lüthi 2014).

Indonesia's social pluralism encourages civil society activists to advocate for civilian interests and bridge the differences between groups to eliminate state infiltration in civilian life. Since the beginning of civil society in Indonesia, most well-known figures in Indonesian civil society were Muslims (Hefner 2018; Hefner 1993; Kadir 1999). As a result, the moderate movement of Islam and civil society, along with their roles in the formation of peace narratives and social activism in the New Order, became the focus among enthusiasts and academics, because of its enduring effect until now (Bünte and Ufen 2008). This is, at least, related to a number of social political factors underlying it. The first factor is related to the deepening of state intervention in constructing ideology and the foundations of citizenship. The New Order had a huge contribution in forming a homogeneous society and group identity, so that civil organizations acted as a buffer for heterogeneous and multicultural communities. The second factor was the massive emergence of civil society movements in the 1980s led by Western universities' graduates, such as Cak Nur, Amien Rais, Syafi'i Maarif (b. 1935) and Dawam Rahardjo (Kadir 1999; Bustamam-Ahmad 2013). The New Order's repressive attitude was not only used to gain political stability, but also to gain legitimacy by involving the military (Crouch 1979).

Civil society first adequately developed alliances, networks and support as social capital. For instance, at the beginning of the formation of civil society in Indonesia in the 1980s, various organizations in Indonesia were able to collaborate with international institutions such as The Asia Foundation and the Ford Foundation for network support and funding. Network expansion to the international level is also seen to legitimize their position (Hefner 2011). On a national scale, strengthening networks is also extended to the two largest Muslim organizations in Indonesia, Nahdlatul Ulama and Muhammadiyah, whose membership includes tens of millions (for further discussion of character and origins of these organizations, see Shabir and Susilo 2018; van Bruinessen 1994; Nakamura 2012). 
Moreover, the development of solidarity between interfaith groups was also well established, where Catholic activists such as Y.B Mangunwijaya (1929-1999), who was well-known as a humanitarian fighter, and a friend of the poor, and Franz Magnis Soeseno (b. 1936) were very actively involved in working with Muslim figures (Park 2012). Supported by large networks, these figures actively voiced the importance of birthing the value of tolerance and pluralism to prevent intercultural tensions and conflicts. In many instances, they also criticized state intervention in religious life (van Bruinessen 1996).

The magnitude of the accumulation of social capital greatly influences the independence of civil society vis-à-vis the state and the success of civil society organizations to achieve their goals (Feillard 1999). The tenacity of civil society succeeded in ending Suharto's rule in 1998 and first succeeded in establishing a truly democratic Indonesian society after its independence in 1945. Commonly called reformasi, this period in Indonesia refers to the end of the New Order in 1998 and the start of democratic governance through direct elections to elect presidents and members of regional and national parliaments. Reformasi elevates some actors of civil society to hold important roles in national politics, such as Abdurrahman Wahid as president in 1999-2001. One of the main objects of contemporary civil society is to form a civil movement independence to continue to construct an established and egalitarian society for all groups. In post-reformasi, awareness of the importance of civil society is increasingly flourishing in Indonesia, and several institutions were established to advocate for civilian interests. Some of these institutions were established, owned and managed by some pioneer families such as the Wahid Institute owned by Gus Dur, Ma'arif Institute owned by Syafi'i Ma'arif, and Paramadina by Cak Nur (Bakti 2005).

The development of civil society in Indonesia is closely related to the accumulation of social capital through various channels. Intercultural and interfaith interactions developed by Indonesian civil society actors during the New Order era greatly influenced the standards of civil society in Indonesia in the post-reformasi era. Such standards as inclusiveness, multiculturalism and tolerance are adequately established by contemporary civil society actors. This is useful to increase public trust in the existence and role of civil society while bridging civil interests in social policies in economic, political and cultural perspectives (Sułkowski 2017; Seda et al. 2018; Strielkowski et al. 2016; Chmielecki and Sułkowski 2018; Danaj et al. 2018).

\subsection{Interfaith Movements and Religious Sensitivity}

As a movement with its institutions and full-time professionals, as well as networks of activists, the concept of civil society is basically only known by modern society. The pressures, since the end of World War II, demanded that the public be able to mobilize existing resources to support peace and the independence of the community from state interests. Some major conflicts between countries in the last quarter of the 20th century very often involved primordial identities such as ethnicity and religion. Initially, the awareness of accumulating resources, by the people in an organized manner, historically often seemed marginal and only carried out individually by eminent philanthropists (Nielson 2002). The rise of conflict and communal tensions has made this method no longer effective, and forced civil society to be institutionally established for the purpose of dialogues for peace. Major religions, along with various large non-profit institutions in the world, accumulate mutual modalities to reach agreements to prevent conflict.

Faith groups are separated by beliefs about divine nature, relationships between individuals and God, the role of religious leaders, forms of worship, norms, and many other prescriptions and prohibitions. But despite these differences, they share key organizing principles and raison d'etre: affiliation based on shared belief of the sacred, however defined (Biscotti and Biggart 2014). The interfaith movement has shifted from the borders of Western society, which apparently began in 1893 at the World Parliamentary Religion meeting in Chicago, to various centers of power throughout the world intensively, which were carried out after the World Trade Center terror attack on 11 September 2001 (Brodeur 2005; Puett 2005). Now, it moves beyond theological discussion and is used in the broad sense of cooperation and dialogue of involvement between individuals who adhere to different religious 
traditions (Jakobsh 2006; Smith 2007). The interfaith movement refers to organized efforts throughout the world to create better understanding and cooperation between and among the world's religious communities (Pedersen 2004). It can be done in at least three ways: informally, institutionally and intellectually. At present, when institutionalization begins to occur in a movement, one immediately begins to use the tools of managerial theory and public relations. To use these tools, the mission statement, goals and objectives must be agreed upon (Kollar 2016).

Interreligious dialogue has an important role to play in building peace, especially in ethnic-religious identity conflicts. Until recently, the field of conflict resolution did not pay enough attention to religious traditions as a source of conflict resolution, and many secularists argued that it was still naive to see inter-religious dialogue as a way to resolve conflicts triggered by religion (Kadayifci-Orellana 2013). There are quite a number of initiatives among young people and women, trying to find ways to work together on projects of justice and local community service (Smith 2007). The goal of interreligious dialogue in a global perspective is the mutual transformation of cultural and religious realities, bringing justice and inclusiveness to all parties by ensuring its purpose in promoting relations between religion and culture in general. Delivering positive changes to harmonious coexistence is a continuous process involving works of many generations (Michaelides 2009).

Civil organizations require readiness in the generation to be willing to engage in interfaith dialogue. Thus, the strong involvement of youth in interfaith dialogue is considered important for sustainable harmony and peace (Michaelides 2009). The implementation of education, training and cadre is usually run by civil organizations with part-time students for the purpose of social dialogue and advocacy. This advocacy sometimes aims to influence decisions in political, economic and social systems, and institutions that seek to facilitate civic engagement and collective action by providing support to those who need it, regardless of religion and other primordial identities (Obar and Lampe 2012). Among the various forms of advocacy, each of which represents a different approach by initiating change in society. One of the most popular forms throughout the growth of the civil movement in Indonesia is advocating social justice related to the idea of defending and upholding the rights of people who are not given the same dignity because of weakness or discrimination. In addition, the interfaith movement also rests on the need for the involvement of many parties with different identities to achieve the organization's mission (Yukich and Braunstein 2014; Park 2012). The nature of this organization should be aligned with the nature of religious organization which basically focuses on the disclosure and strengthening of a shared belief system. The distinctive characteristic of religious organizations, both relevant and observable, is their tendency not to emphasize or make a difference that is not seen among their members, including socio-economic or political differences (Biscotti and Biggart 2014).

As individuals who are educated to bridge inter-group relations, activists should have a delicate appreciation of others' cultures, and be willing to directly participate in society, by identifying and understanding the cues and contexts in social interaction, along with socially respecting the differences. The interfaith movement, in the process, not only encounters and dialogues between religions, but also creates positive adjustments in the form of sensitivity (Chen et al. 2018). In interfaith education, cultural sensitivity implies that both groups understand and respect each other's characteristics, without giving them values-positive or negative, better or worse, right or wrong. Interfaith youth work begins by underlining the importance of religious communities to maintain religious identity and the challenges that the modern pluralist world has towards religious identity (Patel 2006). The strong involvement of youth in interfaith dialogue is considered important for sustainable harmony and peace (Michaelides 2009). Youth organizing groups that have built coalitions for local change over the past few decades now involve young people as leaders in an effort to improve the quality of life. The model of organizing young people was effective in producing impacts at various levels because it formed together youth development, community development, and social change into an integrated organized cycle. This initiative encourages participants by promoting psychological empowerment, leadership development, and socio-political development. At the same time, youth organizing organizations produce impacts at the community level, including the implementation of new programs, policy changes, 
and institutional development. Social change includes intergenerational and multicultural collaboration in exercising power. The interaction between youth development, community development, and social change is discussed in relation to the growing field of youth organizing and other efforts to involve youth in civil society (Christens and Dolan 2011).

\section{Research Method}

\subsection{Research Design}

This research uses a quantitative approach, by analyzing the differences in significance between test groups. This study was conducted by using empirical analysis with psychometric approach using the 29-item Intercultural and Religious Sensitivity Scale Questionnaire (IRSSQ) based on Bennett (1993) Development Model of Intercultural Sensitivity (DMIS). In connection with an analysis that focuses on the possible differences between religions, gender and groups, this study takes a cross-sectional design that focuses on analyzing data from a representation at a particular point in time. Furthermore, this study takes a group with the same sample character, where all participants are interfaith activists. The expected findings are trend indications in intercultural and religious sensitivity among all groups. This is also to reinforce that the sampling of the two groups did not focus on the different tests and did not classify the demographic differences between the two groups in the case-control group. Because of this background similarity between the groups tested, testing in religion-, gender- and group-related differences is more to prove the effectiveness of interfaith education and cadre to increase intercultural sensitivity in young activists.

\subsection{Sampling}

The study was conducted in two interfaith groups that actively advocated for the interests of interfaith relations, namely the Young Interfaith Peacemaker Community (YIPC) led by Andreas Jonathan and Ayi Yunus, and DIAN/Interfidei led by Elga Sarapung. They are contemporary figures in Indonesian civil society who have a wide and influential network. The study took place in Yogyakarta, a city with a population of 636,660, in 2019, which often experienced religious violence along with increasingly religious fundamentalism in the young population. The selection of Yogyakarta as a study location was based on previous research which observed that the Yogyakarta community was a positive example of the role of civil society actors working together to prevent ethnic and religious violence (Park 2012). In addition, the city is seen as one of the most representative places of ethnic and social diversity in Indonesia (de Jong and Twikromo 2017).

YIPC and Interfidei are active in various discussions, cadre training and interfaith activism, with an inclusive membership system from various social organizations from all corners of Indonesia. The IRSSQ analysis in this study was conducted on young activists who attended interfaith cadre training in two Yogyakarta-based organizations. The number of participants who attended three training sessions was less than 100 , so that all participants were taken as respondents. The research was held from October 2018 to April 2019, with the sample chosen being a cadre in one of these two interfaith groups with sufficient knowledge of interfaith relations in the context of cultural and religious diversity in Indonesia.

The psychometric properties of the IRSSQ were tested with empirical samples from 69 cadres who were attending cadre training in these two institutions. The researchers conducted face-to-face screening and briefing with each participant regarding the questionnaire to ensure they understood the context. The research at Interfidei involved a sample of 23 respondents $(33.33 \%)$ who participated in an interfaith youth capacity-building training held in Kaliurang, Yogyakarta in October 2018. Meanwhile, the research at YIPC was conducted on two cadre trainings in camping models in April 2019, with a total sample of 46 respondents (66.67\%), each of which contained 28 in training in the Yogyakarta region in Kaliurang and 18 respondents in training in the Central Java region in Tawangmangu, Karanganyar. Of the 69 questionnaires distributed, only 61 questionnaires were returned (response rate was $88.41 \%$ ). 
Furthermore, filtering data found 4 incomplete questionnaires, so that the remaining 57 questionnaires were worthy of further processing.

For the effectiveness of interfaith dialogue, a number of aspects concerning involvement need to be assessed. First, this dialogue must involve many parties from various religious levels and social and cultural spheres. Yukich and Braunstein (2014) emphasize the need for involvement of lay people and religious leaders in interfaith dialogue. Moreover, a study from Muwahidah (2008) showed that interfaith empowerment efforts led by a group of Catholic activists and students in East Java succeeded in supporting villagers in claiming their land. Accordingly, the selection of respondents in this study is based on the conception that projects of building peace and understanding among religious groups will be influential if not only carried out by religious leaders and scholars, but also involve lay people at the grassroots level. The characteristics of the respondents revealed that most of the respondents adhered to Islam with a total of 39 people $(68.4 \%)$, and the remaining 10 were Protestant adherents $(17.5 \%)$ with 8 Catholics adherents (14\%). In terms of age, the majority of respondents were between 21-25 years old, as many as 30 people (52.3\%), followed by respondents in the age range of 16-20 years, as many as 19 people (33\%), and between $26-30$ years, as many as 7 people (12.3), and one person (1.75\%) did not answer clearly. From the aspect of gender, most (33 people or $57.9 \%$ ) were men, while the rest were women (24 people or $42.1 \%$ ). From educational background, most of them graduated from public high schools, vocational or religious, as many as 41 people $(71.92 \%)$, followed by respondents with a diploma and undergraduate education, as many as 12, and masters, as many as 1 person, and 3 people did not answer. In terms of organizational origin, respondents came from large organizations and affiliates, especially from Muhammadiyah (Ikatan Mahasiswa Muhammadiyah/IMM), Nahdlatul Ulama (Ikatan Pelajar Nahdlatul Ulama/IPNU, NU Garis Lucu, Pergerakan Mahasiswa Islam Indonesia/PMII, and Gerakan Pemuda Ansor/GP. Ansor), Himpunan Mahasiswa Islam (HMI), and students of Sunan Kalijaga State Islamic University and intra-church organizations such as Javanese Christian Church and seminary. There are also those who work as preachers, and adherents of indigenous religion. Nearly half of the participants came from the Central Java and Yogyakarta regions, as many as 28 people ( $49 \%$ ), followed by participants from West Java, East Java and Jakarta metropolitan area (9 people). Participants also came from Lesser Sunda Islands, East Kalimantan, Bangka, Bengkulu, as well as some of Indonesia's most remote islands such as Rote and Natuna. The majority worked as students, as many as 50 people $(87.7 \%)$ and the rest work as farmers, web content writers, pastors, researchers and freelancers (Table 1$)$. Different characters across generations enable education and cadre to be more evenly distributed among all religious organizations involved, and enhance capabilities possessed by interfaith civic organizations to gain support from religious organizations. 
Table 1. Respondent Characteristics.

\begin{tabular}{llll}
\hline Characteristics & Items & Total & Percentage (\%) \\
\hline Religion & Islam & 39 & 68.4 \\
Age & Christian & 18 & 31.6 \\
& $16-20$ & 19 & 33.33 \\
& $21-25$ & 30 & 52.63 \\
Gender & $26-30$ & 7 & 12.28 \\
\multirow{3}{*}{ Last education } & No answer & 1 & 1.75 \\
& Male & 33 & 57.9 \\
& Female & 24 & 42.1 \\
Place of Origin & High school & 41 & 71.93 \\
& Undergraduate & 12 & 21.05 \\
Job & Master & 1 & 1.75 \\
& No answer & 3 & 5.26 \\
& Central Java-Yogyakarta & 28 & 49.12 \\
& East and West Java, Banten, Jakarta & 9 & 15.79 \\
& Other provinces & 20 & 35.09 \\
& Freelance & 1 & 1.75 \\
& Private employees & 1 & 1.75 \\
& College students & 50 & 87.7 \\
& Pastor & 1 & 1.75 \\
& Researcher & 1 & 1.75 \\
& Farmer & 1 & 1.75 \\
& Web Content Writer & 1 & 1.75 \\
\hline
\end{tabular}

\subsection{Variable Measurement}

The aim of this study is to examine the inter-cultural and inter-religious sensitivity of interfaith activists. The research questions are focused on: (1) differences in cultural and religious sensitivity between Muslim activists and Christian activists; (2) differences in intercultural and religious sensitivity between male and female activists; and (3) differences in intercultural sensitivity and religion between YIPC and Interfidei activists.

Previous studies have empirically tested interfaith sensitivity with various models. Hammer and Bennett (1998) developed 50 items in the Inter-Cultural Development Inventory (IDI) to measure individual orientation to cultural differences. Bennett $(1986,1993)$ identified the orientation of cultural differences from ethnocentric and ethnorelative orientations presented in the Intercultural Sensitivity Development Model (DMIS) (Bennett 1993). However, the study of sociology of culture and religion in Indonesia has not explored this kind of orientation in depth, which specifically takes psychometric methods to test this sensitivity.

This study specifically replicates the research of Holm et al. (2009), with different aspects in terms of sample and context. The questions were also slightly modified. Holm et al. (2009) examined the sensitivity of Lutheran students in Finland to the culture of immigrant groups, while this study examined the sensitivity of interfaith activists to religious cultural differences that were inherently centuries old in Indonesia.

Intercultural sensitivity in this study is defined as a sensitivity to the importance of cultural differences and the point of view of people in other cultures (Bhawuk and Brislin 1992). Conceptually, variable measurements refer to the model developed by Bennet regarding ethnocentric and ethnorelative orientations. The ethnocentric orientation refers to standards and habits that apply to a person which are used to judge all people, while ethnorelative orientation refers to being comfortable with many standards and habits, and respecting cultural differences (Bennett 1993; Hammer et al. 2003; Holm et al. 2009). In this context, culture is interpreted as a person's perception of values that should apply in carrying out community life. Someone with an ethnocentric orientation will experience all cultures according to their own culture, while the ethnorelative orientation perceives one's culture in other cultural contexts. 
Both of these orientations are divided into several scales. Ethnocentric orientation is divided into denial, defense, and minimization, while ethnorelative orientation is divided into acceptance, adaptation and integration. Referring to the study of Holm et al. (2009), for defense scale, this study divides in two sub-constructs, namely denigration-superiority and reversal (see the difference in Hammer et al. 2003; Bennett and Bennett 2004). As this study did not examine attitudes regarding mixing people in other cultures, the scale of integration was eliminated (Table 2).

Table 2. Developmental Model of Intercultural Sensitivity, DMIS. (Bennett 1993; Bennett and Bennett 2004).

\begin{tabular}{lllllll}
\hline \multicolumn{2}{l}{ Ethnocentric Orientations } & & & \multicolumn{2}{c}{ Ethnorelative Orientations } & \\
\hline Denial & $\begin{array}{l}\text { Defense } \\
\text { Denigration and } \\
\text { Superiority }\end{array}$ & Reversal & Minimization & Acceptance & Adaptation & Integration \\
& $\begin{array}{l}5 \text { items } \\
6 \text { items }\end{array}$ & 3 items & 7 items & 4 items & 4 items & $\begin{array}{l}\text { Not } \\
\text { included }\end{array}$ \\
\hline
\end{tabular}

Rejection of cultural differences is a situation where the culture itself is experienced as the only real thing. Denial is basically ignorance of the problem of cultural diversity, and seeing other cultures from its own perspective.

Defense against cultural differences is a situation where culture itself is experienced as the only thing that is feasible, and maintains another culture as a threat. Although people in Defense have become proficient in distinguishing differences from those in Denial, they will consider their culture superior and may appear insensitive to cultural differences.

Variation in Defense is Reversal, where the culture adopted is felt to be superior to someone's 'native' culture as the main means of socialization. Reversal is like Defense because it maintains a polarized, 'we' and 'them' worldview.

Minimization is a situation where the elements of one's cultural worldview are experienced as universal. Minimization, superficial cultural differences in recognition of etiquette and other customs are recognized and there is minimal recognition of the similarity of one's own culture and other cultures.

Acceptance represents the initial reconfiguration of the worldview into the cultural context-the ethnorelativism essence. All values, beliefs, and behaviors are arranged in contextual categories that distinguish one set from another.

Adaptation to cultural differences is a situation where other cultural experiences produce perceptions and behaviors that are appropriate to that culture. Adaptation occurs when a person needs to think or act outside of his own cultural context. This need usually occurs when ordinary contact with other cultures becomes more intense, or is in a multicultural society (Hammer et al. 2003; Bennett and Bennett 2004).

For each scale, this study uses a total of 29 question items modified from Holm et al. (2009) with details of 6 question items to measure denial, 5 items for denigration-superiority, 3 items for reversal, 7 items for minimization, and 4 items for acceptance and adaptation. The questions in the questionnaire were arranged randomly and not sequentially to test the sensitivity capacity of activists, and so the answers were natural, or intentional, not to be responded to artificially by the respondent, by giving a high value to a particular construct and giving a low value to another construct. This is consistent with the aim of this study, that interfaith activists should have standards and capabilities that are compatible with their movement's mission, are inclusive of all groups and reject conservatism. That is, they should have a low ethnocentric orientation, which is reflected by low values in ethnocentric constructs, and have good intercultural sensitivity reflected by the high value of ethnorelative orientation. The scale used for the data analysis process is a 5-point Likert Scale for all items, from 1 (strongly disagree) to 5 (strongly agree). 


\subsection{Data Analysis}

The first test is to analyze the characteristics of respondents and descriptive data. To test data quality, testing reliability and validity is done first. Furthermore, the correlation test between constructs was tested by the Pearson test. Furthermore, to test the differences in sensitivity between groups (gender, religion and organizations), the research data were analyzed by the Mann-Whitney U-test nonparametric test.

\section{Results}

\section{Confirmatory Factor Analysis, Reliability and Validity}

Confirmatory factor analysis of ethnocentric constructs showed that denial items have mean values in the range of 1.49 (irssq_11) to 3.88 (irssq_29), denigration/superiority items have mean values from 1.37 (irssq_05) to 4.60 (irssq_28), reversal items from 1.53 (irssq_17) to 4.74 (irssq_26), and minimization items from 1.32 (irssq_13) to 4.19 (irssq_18). For ethnorelative constructs, acceptance items have mean values in the range of 1.33 (irssq_06) to 4.63 (irssq_21), and mean values of adaptation items range from 2.11 (irssq_07) to 3.95 (irssq_16). In reversal items, mainly items irssq_15 and irssq_26 about the respondents' perception of intra-faith tolerance and exclusivism have high mean values. In this context, they felt symptoms of conservatism were increasingly growing among their religion's adherents (intra-faith perception). Reversal is an attempt to analyze a person's form of self-defense to assume that culture or religion itself is inferior or superior to other people's religions. In interreligious relations, the perception of perceived threat of religious outgroups is a reflection of the content of reactivity in other groups (Choma et al. 2016). On the other hand, the study revealed that activists also saw that adherents of their own religion were a threat to interfaith relations. However, activists do not consider that "people of their religion are more cruel than people who represent other religions," (irssq_17) with a mean of 1.53 (Table 3). For them, increasing conservatism among followers of religion does not reach the level of the real threat of followers of religion by acting out of bounds to oppress other groups. In addition, a low response to the cruelty of followers of religion is in accordance with the values of pluralism emphasized in interfaith education, where the non-exclusionist attitude with any group is a necessity for the effectiveness and efficiency of problem solving, and suspicion can result in the consequences of not accepting activists in a certain group. Inclusive and justice oriented-values are the core for organizations involved in interfaith dialogue. These values are inextricably related because there are many injustices experienced by the religious community, and interfaith communities need to advocate for their constituents to achieve full access to their rights.

For ethnorelative orientations, the results derived from acceptance and adaptation items show mean values of 3.28 and 4.18, respectively (Table 4). This value confirms that activists tend to have interfaith sensitivity in a good range. In terms of awareness of accepting religious differences, activists think that world religions are different because of differences in issues that are considered important and valuable for each group (irssq_21), and that "people from different religions use face expressions and gestures that are different from what they do" (irssq_20). They also gave moderate responses to adaptations items to develop inclusive thinking through different thoughts and behaviors (irssq-27), to enable them to see others in new ways (irssq_16). Activists generally gave low values on aspects of ethnocentrism and are relatively willing to accept differences between religions. This allows them to be actively involved in interfaith dialogue, and enables them to advocate for public interests related to cultural and religious differences more intensively. The results also show that intimate sensitivity is a product of cultural and religious diversity in Indonesia that continues to be developed and maintained. According to Blakemore (2019), advocates of faith-based diplomacy support that combining faith into peace activities helps reduce identity-based conflict and religious violence, by pursuing social cohesion through dialogue and equality between religions (Catto 2017). 
Table 3. Intercultural and Religious Sensitivity Scale Questionnaire (IRSSQ) items.

\begin{tabular}{|c|c|c|c|c|}
\hline No & Symbol & Items & Label & M (SD) \\
\hline 01 & irssq_01 & Minimization & I think everyone is the same even though there is a slight difference in belief. & $3.37(1.62$ \\
\hline 02 & irssq_02 & Denial & In my opinion, the more we bring the issue of belief to the public space, the more it causes problems. & $3.25(1.58$ \\
\hline 03 & irssq_03 & Denial & $\begin{array}{l}\text { I do not consider myself an exclusive person, but I think my belief must dominate the discourse in } \\
\text { the public sphere. }\end{array}$ & $2.23(1.34$ \\
\hline 04 & irssq_04 & Denigration/Superiority & I believe that other people must use the principle of teaching in our beliefs as a model of how to live their lives. & $1.49(0.89$ \\
\hline 05 & irssq_05 & Denigration/Superiority & I think my own beliefs are the only ones that are right. & $1.37(0.86$ \\
\hline 06 & irssq_06 & Acceptance & $\begin{array}{l}\text { I think students from other faiths should be instructed to take our religion lessons because they will learn a lot of } \\
\text { manners and their views. }\end{array}$ & $1.33(0.72$ \\
\hline 07 & irssq_07 & Adaptation & I can put myself in someone's position from other beliefs. & $2.11(1.29$ \\
\hline 08 & irssq_08 & Denial & $\begin{array}{l}\text { I assume that a misunderstanding situation will easily occur in religious studies if there are other } \\
\text { faith students present. }\end{array}$ & $2.40(1.62$ \\
\hline 09 & irssq_09 & Minimization & $\begin{array}{l}\text { I believe that everyone will act in almost the same way when they have to consider whether their actions are right } \\
\text { or wrong. }\end{array}$ & $1.32(0.66$ \\
\hline 10 & irssq_10 & Minimization & I think that other people must move to my religion. & $2.00(1.15$ \\
\hline 11 & irssq_11 & Denial & I don't want to attend religious lessons with students from various religions. & $1.49(0.89$ \\
\hline 12 & irssq_12 & Acceptance & $\begin{array}{l}\text { In my opinion, this (point 11) can cause a misunderstanding, when people from different religions and cultures } \\
\text { express their feelings in different ways. }\end{array}$ & $2.56(1.52$ \\
\hline 13 & irssq_13 & Adaptation & When I meet people from other faiths and cultures, I try to act their way. & $2.12(1.32$ \\
\hline 14 & irssq_14 & Denigration/Superiority & I am not interested in other religions or cultures because I think I don't need to know anything about them. & $3.07(1.57$ \\
\hline 15 & irssq_15 & Reversal & I think people of our religion are less tolerant of people who are different from us. & $4.40(1.21$ \\
\hline 16 & irssq_16 & Adaptation & I think different behaviors and different ways to act make me see things in new ways. & $3.95(1.34$ \\
\hline 17 & irssq_17 & Reversal & I think people from my religion are more cruel than people who represent other religions. & $1.53(0.89$ \\
\hline 18 & irssq_18 & Minimization & I am sure that everyone is basically the same regardless of religious differences. & $4.19(1.36$ \\
\hline 19 & irssq_19 & Minimization & I think other religious people are exclusive or less open. & $2.04(1.21$ \\
\hline 20 & irssq_20 & Acceptance & $\begin{array}{l}\text { I have noticed that people from different religions use facial expressions and gestures that are different from what } \\
\text { we do. }\end{array}$ & $4.40(1.08$ \\
\hline 21 & irssq_21 & Acceptance & $\begin{array}{l}\text { I think that world religions are different because of differences in issues that are considered important and } \\
\text { valuable to them. }\end{array}$ & $4.63(0.84$ \\
\hline 22 & irssq_22 & Denigration/Superiority & I think other people are less tolerant than us. & $3.61(1.54$ \\
\hline 23 & irssq_23 & Minimization & I think people all over the world need and want things that are more or less the same. & $2.68(1.58$ \\
\hline 24 & irssq_24 & Denial & $\begin{array}{l}\text { I believe that the right thing is if people don't have to deal with people who come from different } \\
\text { cultures and religions. }\end{array}$ & $3.04(1.58$ \\
\hline 25 & irssq_25 & Minimization & $\begin{array}{l}\text { I think all conflicts between different cultures and religions can be solved by adhering to the same } \\
\text { ethical principles. }\end{array}$ & $3.79(1.48$ \\
\hline 26 & irssq_26 & Reversal & I find people from our group more exclusive than other religious groups. & $4.74(0.67$ \\
\hline 27 & irssq_27 & Adaptation & I noticed that different thoughts and behaviors changed my behavior too. & $3.53(1.51$ \\
\hline 28 & irssq_28 & Denigration/Superiority & $\begin{array}{l}\text { I think people who represent other cultures or religions are so stupid that they figuratively can trap } \\
\text { themselves in ignorance. }\end{array}$ & $4.60(0.84$ \\
\hline 29 & irssq_29 & Denial & I think caring about socio-religious issues is a waste of time. & $3.88(1.42$ \\
\hline
\end{tabular}


Table 4. Descriptive statistics of IRSSQ constructs.

\begin{tabular}{llccccc}
\hline Constructs & Item Number & Min & Max & M & S.D & Cronbach's $\alpha$ \\
\hline Denial & $\begin{array}{l}\text { irssq_02, irssq_03, irssq_08, } \\
\text { irssq_11, irssq_24, irssq_29 }\end{array}$ & 1.00 & 4.00 & 2.17 & 0.65 & 0.484 \\
$\begin{array}{l}\text { Denigration/Superiority } \\
\text { Reversal }\end{array}$ & $\begin{array}{l}\text { irsq_04, irssq_05, irssq_14, } \\
\text { irssq_15, irssq_28 }\end{array}$ & 1.00 & 3.40 & 1.86 & 0.64 & 0.424 \\
Minimization & $\begin{array}{l}\text { irssq_01, irssq_09, irssq_26 } \\
\text { irssq_18, irssq_19, irssq_23, }\end{array}$ & 1.00 & 5.00 & 2.58 & 1.13 & 0.643 \\
Acceptance & $\begin{array}{l}\text { irssq_25 } \\
\text { irssq_06, irssq_12, irssq_20, }\end{array}$ & 1.00 & 4.43 & 3.59 & 0.58 & 0.512 \\
irssq_21 & $\begin{array}{l}1.00 \\
\text { Adssq_07, irssq_13, irssq_16, } \\
\text { irssq_27 }\end{array}$ & 2.50 & 5.00 & 4.18 & 0.62 & 0.152 \\
\hline
\end{tabular}

Intercultural sensitivity scale analyses are presumably very closely related to reliability issues due to the high tendency of local cultural biases, thereby influencing the adoption in different cultural contexts (Fritz et al. 2001; Greenholtz 2005; Holm et al. 2019; Kuusisto et al. 2014; Yuen and Grossman 2009; Tamam 2010). Wu (2015) adds that cultural differences are more likely to affect the factor structure of an intercultural sensitivity test. Statistical analysis shows the reliability and validity values for the six IRRSQ dimensions. Denial construct consisting of six items had the alpha value of 0.484 . Reversal with five items obtained alpha $=0.424$. Denigration/superiority with three items had the alpha value of 0.643 and minimization with seven items obtained the alpha value of 0.512 . For ethno-relative constructs, acceptance with four items and adaptation with four items, respectively, obtained the alpha values of 0.155 and 0.168 . The low reliability is not unique to this study. Dong et al. (2008) found low reliability values in the sensitivity of intercultural communication in young adults in the United States. Demircioglu and Cakir (2016) revealed similar problems for the case of Turkey, and Petrović et al. (2015) found several items with low reliability in analyzing cultural sensitivity in Serbia. Previous studies also confirmed that the incompatibility of sensitivity constructs for each cultural context is a main reason for the low reliability (Wu 2015; Fritz et al. 2001; Tamam 2010). Misunderstanding of participants choosing a particular response or using another strategy in a situation is also the cause of this problem. Petrović et al. (2015) added that the complexity of language or hidden intentions of participants can also affect the low reliability. Interfaith sensitivity analysis using IRSSQ items from Holm et al. (2009), also found that some ethnorelative constructs (acceptance and integration) had low reliability values while ethnocentric constructs (denial and denigration/superiority) had high reliability values. Holm et al. (2009) argue that low alpha is related to scale dimensions. Moreover, the concept of the level of abstraction that requires high understanding is more likely to be difficult to apply to intuitive items. Fritz et al. (2001) revealed that the low reliability coefficient might require the addition of new items to capture the measured concept. Modifying the questionnaire compared to its original form or by using finer diagnostic instruments from confirmatory factor analysis to improve reliability were also suggested in several findings (Wu 2015; Wang and Zhou 2016; Fritz et al. 2001).

The results show a significant and positive correlation on the relationship between denial and denigration/superiority $(0.519, p=0.000)$, with reversal $(0.418, p=0.001)$, and with acceptance $(0.455$, $p=0.000$ ). Meanwhile, the correlations between other variables are low and not significant (Table 5). The low value of this correlation is related to the low value of reliability. According to Griffith et al. (2016), low reliability is more likely to decrease the correlation coefficient below the level rather than when reliability is high. 
Table 5. Pearson Correlation.

\begin{tabular}{cccccc}
\hline Constructs & Denigration/Superiority & Reversal & Minimization & Acceptance & Adaptation \\
\hline \multirow{2}{*}{ Denial } & $0.519^{* *}$ & $0.418^{* *}$ & 0.153 & $0.455^{* *}$ & 0.038 \\
& $(0.000)$ & $(0.001)$ & $(0.257)$ & $(0.000)$ & $(0.778)$ \\
Denigration/superiority & - & 0.175 & $0.308^{*}$ & $0.262^{*}$ & -0.014 \\
& & $(0.194)$ & $(0.020)$ & $(0.049)$ & $(0.918)$ \\
Reversal & - & - & 0.047 & $0.295^{*}$ & 0.052 \\
Minimization & - & - & $-0.731)$ & $(0.026)$ & $(0.703)$ \\
Acceptance & - & - & - & 0.115 & -0.025 \\
& - & & - & $-0.396)$ & $(0.852)$ \\
& & & & -0.055 \\
\end{tabular}

${ }^{* *}$ significant at the 0.01 level (2-tailed), ${ }^{*}$ significant at the 0.05 level (2-tailed).

\section{Hypothesis Testing}

\subsection{Intercultural and Religious Sensitivity between Muslim and Christian Activists}

The results of the study between different religions show that in all good contexts, Muslim activists and Christian activists have a uniform view, giving low values to the scales of ethnocentric orientations and giving higher values to the ethnorelative scales. The results showed no significant differences between the two groups of Muslim and Christian activists in responding to ethnocentric and ethnorelative orientations ( $p$-value $>0.05$, for all constructs) (Table 6).

Table 6. Religious-related differences of IRSSQ constructs.

\begin{tabular}{lccc}
\hline Constructs & $\begin{array}{c}\text { Muslim } \\
(\mathbf{n}=\mathbf{3 9 )}\end{array}$ & $\begin{array}{c}\text { Christian } \\
(\mathbf{n}=\mathbf{1 8})\end{array}$ & $\mathbf{Z}(\boldsymbol{p}$-Value) \\
\hline & $M(S D)$ & $M(S D)$ & \\
Denial & $2.16(0.57)$ & $2.19(0.79)$ & $-0.242(0.809)$ \\
Denigration/superiority & $1.84(0.66)$ & $1.91(0.61)$ & $-0.502(0.616)$ \\
Reversal & $2.66(1.16)$ & $2.41(1.06)$ & $-0.657(0.511)$ \\
Minimization & $3.62(0.59)$ & $3.54(0.56)$ & $-0.855(0.393)$ \\
Acceptance & $3.23(0.84)$ & $3.26(0.82)$ & $-0.130(0.896)$ \\
Adaptation & $4.14(0.65)$ & $4.28(0.57)$ & $-0.739(0.460)$ \\
\hline
\end{tabular}

Our findings indicate that both interfaith groups show the same view regarding rejection on ethnocentric orientations and acceptance on ethnorelative constructs. These results confirm that interreligious sensitivity testing in both Muslim and Christian groups head-to-head has no difference in view. The absence of significant differences between the two groups represents the interreligious understanding that has been well established in interfaith education. This is indicated with rising value trends from ethnocentric to ethnorelative contructs. The results highlight that the two groups agreed to reject chauvinistic views, and open themselves to an inclusive view and accept differences between groups.

The results are consistent with previous studies on IRSSQ testing in various cultural settings. Using the Interreligious Sensitivity Scale Questionnaire/IRSSQ, the Kuusisto et al. (2016) study analyzing students' attitudes toward interfaith sensitivity identified four religious profiles consisting of highly religious, culturally religious, personally religious and non-religious, found that in the Finnish socio-demographic context, interfaith sensitivity of non-religious groups was more marked by denial and low acceptance than other groups. This also confirms that empirical testing of school students with different religious backgrounds will be more likely to find a significant difference in relation to differences in the character and religious outlook of other groups. In a similar context, Kimanen and Kuusisto (2017) also found that in the setting of atheist students, they assumed that religion did not exist. In the context of religious differences, such outlooks may originate from religious expressions, 
individual or group worldviews, and social interaction. This finding confirms that the high level of social interaction and the similarity of worldviews on religious differences between the groups tested are more likely to obtain a uniform view among groups. Miedema (2014); Knauth (2007); Patrick (2015) stated social interaction and the similarity of worldviews can be maximized through encounters, social involvement, cooperation and interfaith education. McKenna et al. (2009) found that students with commitment to religious values and worldviews would be more likely to be tolerant in their views and open to interreligious learning. Furthermore, aspects related to life phases and their contingent pressures in religious education are proven to influence students' religious commitments and beliefs (McKenna et al. 2009). Furthermore, Ipgrave and McKenna (2008) also found that the promotion of an educational model that emphasizes the principle of acceptance and respect for cultural differences can enhance assimilation and ethical views among religious adherents. This affirms Dong et al. (2008), that intercultural and multiculturalism communication are strategic steps to increase intercultural sensitivity, reduce conflict in interactions between groups, and overcome ethnocentrism.

\subsection{Intercultural and Religious Sensitivity between Female and Male Activists}

The results of intercultural sensitivity testing with gender differentiation prove that there is no sensitivity between the two gender groups in all constructs, with a $p$-value $>0.05$. Both gender groups also show their disapproval of aspects of ethnocentrism and give high values to aspects of acceptance and adaptation in other cultures (Table 7).

Table 7. Gender-related differences of IRSSQ constructs.

\begin{tabular}{lccc}
\hline \multirow{2}{*}{ Constructs } & Male $(\mathbf{n}=\mathbf{3 3})$ & Female $(\mathbf{n}=\mathbf{2 4})$ & \multirow{2}{*}{$\mathbf{Z}(\boldsymbol{p}$-Value) } \\
\cline { 2 - 3 } & $\boldsymbol{M}(\boldsymbol{S D})$ & $\boldsymbol{M}(\boldsymbol{S D})$ & \\
\hline Denial & $1.67(0.56)$ & $1.87(0.85)$ & $-0.775(0.438)$ \\
Denigration/superiority & $1.52(0.62)$ & $1.58(0.65)$ & $-0.382(0.702)$ \\
Reversal & $2.33(1.08)$ & $2.12(1.07)$ & $-0.857(0.392)$ \\
Minimization & $3.09(0.68)$ & $3.29(0.62)$ & $-1.108(0.268)$ \\
Acceptance & $2.90(0.87)$ & $3.08(0.77)$ & $-0.764(0.445)$ \\
Adaptation & $3.97(0.68)$ & $3.87(0.79)$ & $-0.364(0.716)$ \\
\hline
\end{tabular}

The findings generally reveal that there were no significant differences between genders in the six interreligious sensitivity constructs used in this study. The finding is in accordance with Yurtseven and Altun (2015) who found no significant difference in the level of interfaith sensitivity according to sex. Similarly, the findings of Haugen (2017) also found no clear differences in interfaith sensitivity between women and men. Different findings were stated by Holm et al. (2009), that there are significant differences between male and female students in ethnocentric constructs. Holm et al. (2009) further explained that the tendency to avoid other cultures by expressing disinterest and aggressive attitudes towards other religions was stronger for men than for women. The difference in research objects is henceforth worth highlighting, where testing in the educated group through intercultural understanding, as in Yurtseven and Altun (2015), showed insignificant results among genders, while testing in students such as in Holm et al. (2009) who did not get certain actions beforehand such as intercultural teaching and understanding were likely to tend to get significant results. This proves that teaching and understanding in class about intercultural and multicultural values is more likely to evenly increase intercultural sensitivity among genders.

In particular, the results of the study also revealed that women had higher mean scores than men for the construct of acceptance $(\mathrm{M}=3.08, \mathrm{SD}=0.77$, compared to $\mathrm{M}=2.90, \mathrm{SD}=0.87$ for male). This confirms the findings of Grigaityte et al. (2019), who found that women, compared to men, were more likely to be willing to invest in efforts to accept groups with different cultures. Furthermore, Grigaityte et al. (2019) also noted that the scale of proactive attitudes towards integration of women scored higher 
than men. This shows that the higher female ethnorelative degree is related to prosocial traits. Holm et al. (2009) also stated that females are more empathic than males in looking at cultural differences.

Practically, the results promoted interfaith activism education to provide a proportionate role for women to engage in interfaith dialogue. Holm et al. (2019) emphasized that the development of gender-sensitive educational practices can balance gender-related differences in interreligious sensitivity. Women activists in our study have the same opportunities, tasks and teachings in interfaith education to present peace values such as positive self-concept, celebrating diversity, overcoming conflict without violence and caring for nature. In both organizations, women are actively involved in various activities, and there is no special distinction in gaining activism education. In our study, the head of Interfidei, Elga Sarapung is a woman who is very active in promoting peace values at the national and international levels. Peaceful educational material has been widely known in interfaith education and peacebuilding. This is consistent with the arguments of Gebregeorgis (2017) regarding recurring peace values that include tolerance and solidarity, positive self-concept, and respect for life and care for the environment.

Our findings are also connected to the socio-cultural conditions of Indonesia, which do not emphasize gender segregation (Rokhmad and Susilo 2017). This condition allows women's involvement in interfaith forums. In some cases, the presence of women in social advocacy can facilitate conflict resolution. Dugan (2007) presented the vital role of women in introducing religious principles to their communities and people from various religious traditions.

\subsection{Differences in Sensitivity between Organizations}

Furthermore, from organizational differences, the results of testing the IRSSQ constructs present significant differences in both organizations, YIPC and Interfidei, in terms of denial and acceptance. For the denigration/superiority construct, reversal, minimization and adaptation, there were no significant differences between the two organizations, with a $p$-value $>0.05$. In denial constructs, the average produced by YIPC activists is $2.33(\mathrm{SD}=0.66)$, and Interfidei $1.92(\mathrm{SD}=0.56)$, with a value of $Z-1.988$ ( $p$-value $=0.047<0.05)$. Lower denial values show disagreement on higher ethnocentrism, and in this case, Interfidei is better at rejecting ethnocentrism. For acceptance aspects, the mean values of the two groups are $4.24(\mathrm{SD}=0.64)$, and $4.08(\mathrm{SD}=0.59)$, for YIPC and Interfidei, respectively. Higher values of acceptance show better ethnorelativism essence of outside culture, and in this case, YIPC activists have a more sensitive view of accepting cultural differences, with a value of $\mathrm{Z}-0.507$ ( $p$-value $0.012<0.05)$ (Table 8$)$.

Table 8. Organization-related differences of IRSSQ constructs.

\begin{tabular}{lccc}
\hline \multirow{2}{*}{ Constructs } & YIPC $(\mathbf{n}=\mathbf{3 7})$ & Interfidei $(\mathbf{n}=\mathbf{2 0})$ & \multirow{2}{*}{$\mathrm{Z}(\boldsymbol{p}$-Value $)$} \\
\cline { 2 - 3 } & $\boldsymbol{M}(\boldsymbol{S D})$ & $\boldsymbol{M}(\boldsymbol{S D})$ & \\
\hline Denial & $2.31(0.66)$ & $1.92(0.56)$ & $-1.988(0.047)$ \\
Denigration/superiority & $1.91(0.65)$ & $1.77(0.63)$ & $-1.037(0.300)$ \\
Reversal & $2.50(1.08)$ & $2.73(1.23)$ & $-0.707(0.480)$ \\
Minimization & $3.57(0.58)$ & $362(0.59)$ & $-0.118(0.906)$ \\
Acceptance & $3.48(0.79)$ & $2.91(0.77)$ & $-2.507(0.012)$ \\
Adaptation & $4.24(0.64)$ & $4.08(0.59)$ & $-1.237(0.216)$ \\
\hline
\end{tabular}

The findings are also in line with Chen (2010) stating that intercultural sensitivity is negatively related to ethnocentrism. Differences in organizational culture and educational methods are closely related to affect intercultural sensitivity between groups. Abu-Nimer (2001) states that cultural differences can lead to differences in acceptance of individual values, and interfaith organizations henceforth act as providers of resources and actions plans. Abu-Nimer (2001) states that the internalization of multicultural values offered by interfaith organizations at the national or international level can motivate the similarity of perceptions, attitudes and actions among group members. For this 
reason, interfaith organizations are needed to be an integral part of interaction between individuals and groups by emphasizing understanding of religious values, norms, systems and behavior. This is in accordance with Kimanen and Kuusisto (2017), that interfaith education is suggested to create a peaceful culture and dialogue and accommodate various types of social interaction.

Rissanen et al. (2016) revealed a process of self-reflective learning about culture and religion in education can encourage students' willingness to engage in self-reflection as the basis needed to develop an ethno-relative orientation to sensitivity towards socio-cultural diversity and religious identity. Kuusisto et al. (2014) found that demographic variance and students' religious affiliation influenced students' interfaith sensitivity in Finland. Tamam and Krauss (2017) found that the level of involvement of ethnic diversity was positively related to the level of intercultural sensitivity. This shows that the outlook of the organization and interfaith education has an influential role in the process of encounters and dialogue among groups.

In a multicultural society like Indonesia, the task of activists across faith is to eliminate prejudice between groups and build tolerance and respect between groups. In countries with high socio-cultural diversity, multiculturalism is not just a difference of identity and political recognition, but is manifested in encounters, acculturation and assimilation of different cultures. Multicultural education needs to be emphasized in all genders and religions to combat racism, exclusion and to protect minority communities (Susilo and Dalimunthe 2019). In the context of civil society, intercultural education also plays a role in ensuring that young people and activists have an inclusive and tolerant attitude towards cultural differences to advocate for the fulfillment of civil rights and prevent excessive state intervention in civil aspects. Finally, intercultural sensitivity to youth is expected to help undo state policies that can potentially prevent minorities from having full access to opportunities for freedom and equality in public life.

\section{Concluding Remarks}

The findings of this study indicate that there is no significant difference in intercultural sensitivity in all constructs of ethnocentric orientation and ethonorelative orientation between religion and between genders. The significant difference in sensitivity in rejection and acceptance between the two organizations has implications for the two organizations to strategically emphasize interfaith education and acceptance of different cultural identities and reject exclusivity. These findings generally indicate the existence of standards and views held by interfaith activists in Indonesia, as the main drivers of civil society. The task of intercultural activism is to maintain multiculturalism as an inherent cultural system in Indonesia, and they must continue to advocate the importance of maintaining intercultural and multicultural interaction and communication with the public. Interfaith youth groups need to provide specific subjects on the use of multiculturalism-based ideas and advocacy in practices and policies, and in helping to solve public problems, especially related to actual issues involving pluralism, inclusivism, democracy, tolerance, freedom of religion, and discrimination.

The findings show that activists are more likely to be less religiously dogmatic in responding to cultural differences. They are more likely to consider social and religious diversity in Indonesia's cultural landscape, and have a balanced understanding of interfaith perceptions and interfaith threats. The results of this study theoretically confirm previous studies that encourage the promotion of education and interfaith meetings to overcome the threat of ethnocentrism and increase interaction amidst the diversity of socio-cultural identities. In addition, this study also encourages the strengthening of comprehension, competence and communication in intercultural sensitivity in young people across Indonesia.

In its relationship with civil society, the role of interfaith activists is very influential in maintaining independence from political and state intervention. This will make it easier for all parties to accept advocacy from civic groups, and enable interfaith organizations to help marginalized groups claim their rights. In cases of conflict, interfaith civil actors have played an important role in preventing ethnic violence. In the case of Indonesia, particularly in Yogyakarta, strong civic engagement was proven 
capable of preventing violence and ethnic sentiment during the conflict (Park 2012). More broadly, civic engagement in Eastern countries is needed to increase the effectiveness of interfaith dialogue and maintain social harmony and multiculturalism (Hunt 2009; Ayrookuzhiel 1994; Yilmaz and Barry 2018). Meanwhile, interfaith dialogue in Western democracies has become a specific subject along with European unification and increased cross-border migration. Intercultural encounters, in turn, fostered multiculturalism as a special consideration in public policy in Europe. There is a tendency to emphasize the role of multiculturalism in shaping national culture, and the use of multiculturalism-based ideas and actions in policy and cultural advocacy, democratic development, tolerance, religious freedom, and anti-discrimination (Bilan et al. 2019; Simionescu et al. 2017; Bilan 2012).

The limitation of this study lies mainly in the low Cronbach Alpha value on most IRSSQ constructs. Conceptually, the low value may be related to the construct non-conformity for the Indonesian context. This study adopts items from Holm et al. (2009) with subjects in Finland having different socio-demographic landscapes from Indonesian multicultural societies. Future studies are expected to test the reliability and validity of the IRSSQ in the context of multicultural societies and contextualize items according to local culture and modify them.

The objection that could arise regarding the specific subject of the research is the not high consistency of the sample selected in the two groups. Here, the findings are more meaningful as an indication of trends from interfaith groups that are culturally and religiously motivated. The results achieved are indicative of cultural trends in minority groups, active and dynamic in the accumulation of social capital. Future studies are expected to be able to test IRSSQ in school students or young adult groups to obtain different results. In addition, alternative methods for testing the effectiveness of interfaith education can use several intercultural sensitivity analysis tools such as Chen and Starosta (2000) models of intercultural sensitivity, intercultural communication sensitivity (ICCS) or intercultural communication competence (ICC), or intercultural and interethnic communication apprehension scales.

Author Contributions: Conceptualization, S.S.; data curation, J.H.K.; formal analysis, S.S.; investigation, J.H.K.; methodology, S.S.; project administration, J.H.K.; validation, S.S.; visualization, J.H.K. All authors have read and agreed to the published version of the manuscript.

Funding: This research received no external funding.

Acknowledgments: We would like to thank Elga Sarapung and Otto Adi Yulianto (Interfidei), Andreas Jonathan and Ayi Yunus (YIPC) and facilitators in the two organizations for the opportunity given to us to conduct research and valuable discussions. We are also immensely grateful to Claire Smith and Amanda Kearney as Special Issue editors for accepting our manuscript. We would also like to show our gratitude to Jasmine Yang for sincerely helping us in the publication process, and anonymous reviewers for their constructive criticism and suggestions. We dedicate this work to activists in interfaith dialogue for their sincerity in an effort to bridge differences and peacebuilding. Finally, this work would not have been possible without the love and support of our family, Jamari, Erna Purwati and Desi Setya Ngaeni, Izzakhild Ailani Sulistyo.

Conflicts of Interest: The authors declare no conflict of interest.

\section{References}

Al Qurtuby, Sumanto. 2015. Interethnic Violence, Separatism and Political Reconciliation in Turkey and Indonesia. India Quarterly 71: 126-45. [CrossRef]

Aspinall, Edward. 2004. Transformation of Civil Society and Democratic Breakthrough. In Civil Society and Political Change in Asia: Expanding and Contracting Democratic Space. Edited by Muthiah Alagappa. California: Stanford University Press, pp. 61-96.

Ayrookuzhiel, A. M. Abraham. 1994. The Dalits, Religions and Interfaith Dialogue. Journal of Hindu-Christian Studies 7: 13-19. [CrossRef]

Azra, Azyumardi. 2007. Religious-based Civil Society and Anti-Corruption Campaign: The () Indonesian Experience in the Creation of Good Governance. In Civil Society, Religion and Global Governance: Paradigms of Power and Persuasion. Edited by Helen James. London and New York: Routledge, p. 288.

Bakti, Andi Faisal. 2005. Islam and Modernity: Nurcholish Madjid's Interpretation of Civil Society, Pluralism, Secularization, and Democracy. Asian Journal of Social Science 33: 486-505. [CrossRef] 
Bennett, Milton. 1986. Towards Ethnorelativism: A Developmental Model of Intercultural Sensitivity. In Cross-cultural Orientation: New Conceptualizations and Applications. Edited by Paige R. Michael. New York: University Press of America, pp. 27-69.

Bennett, Milton. 1993. Towards Ethnorelativism: A Developmental Model of Intercultural Sensitivity. In Education for the Intercultural Experience. Edited by Paige R. Michael. Yarmouth: Intercultural Press, pp. 21-71.

Bennett, Janet, and Milton Bennett. 2004. Developing Intercultural Sensitivity. An Integrative Approach to Global and Domestic Diversity. In Handbook of Intercultural Training. Edited by Dan Landis, Janet Bennett and Milton Bennett. Thousand Oaks: Sage, pp. 147-65.

Bertrand, Jacques. 2002. Legacies of the Authoritarian Past: Religious Violence in Indonesia's Moluccan Islands. Pacific Affairs 75: 57-85. [CrossRef]

Bhawuk, Dharm P. S., and Richard Brislin. 1992. The Measurement of Intercultural Sensitivity Using the Concepts of Individualism and Collectivism. International Journal of Intercultural Relations 16: 413-36. [CrossRef]

Bilan, Yuriy. 2012. Specificity of Border Labour Migration. Transformations in Business E Economics 11: 82-97.

Bilan, Yuriy, Mihaela Simionescu, Sergej Vojtovič, and Sergii Zapototskyi. 2019. The Impact of Religiosity on Individual Perception of Wellbeing and Living Standards: A Cross-cultural Study on Selected Developing Economies. Journal of Population and Social Studies [JPSS] 27: 347-58. [CrossRef]

Biscotti, Dina, and Nicole Woolsey Biggart. 2014. Organizing Belief: Interfaith Social Change Organizations in the Religious-Environmental Movement. In Religion and Organization Theory. Edited by Paul Tracey, Nelson Phillips and Michael Lounsbury. Bingley: Emerald Group Publishing Limited, pp. 413-39.

Blakemore, Scott. 2019. Faith-based Diplomacy and Interfaith Dialogue. Brill Research Perspectives in Diplomacy and Foreign Policy 3: 1-124. [CrossRef]

Brodeur, Patrice. 2005. From the Margins to the Centers of Power: The Increasing Relevance of the Global Interfaith Movement. CrossCurrents 55: 42-53.

Bünte, Marco, and Andreas Ufen. 2008. The New Order and Its Legacy: Reflections on Democratization in Indonesia. In Democratization in Post-Suharto Indonesia. Edited by Marco Bünte Andreas Ufen. New York: Routledge, pp. 23-50.

Bustamam-Ahmad, Kamaruzzaman. 2013. Contemporary Islamic Thought in Southeast Asia:"Islam Liberal","Islam Hadhari", and "Islam Progresif". In Islamic Thought in Southeast Asia: New Interpretations and Movements. Edited by Kamaruzzaman Bustamam-Ahmad and Patrick Jory. Kuala Lumpur: University of Malaya Press, pp. 21-44.

Carothers, Thomas. 1999. Civil Society: Think again. Foreign Policy 117: 18-29. [CrossRef]

Catto, Rebecca. 2017. Interfaith Dialogue and the Challenge of Indifference: Reflections from Fieldwork in the City of Peace and Reconciliation. In Religious Indifference: New Perspectives From Studies on Secularization and Nonreligion. Edited by Johannes Quack and Cora Schuh. Cham: Springer, pp. 65-82.

Chen, Guo-Ming. 2010. The Impact of Intercultural Sensitivity on Ethnocentrism and Intercultural Communication Apprehension. Intercultural Communication Studies 19: 1-9.

Chen, Guo-Ming, and William J. Starosta. 2000. The Development and Validation of the Intercultural Sensitivity Scale. Human Communication 3: 1-15.

Chen, Xinyin, Rui Fu, Junsheng Liu, Li Wang, Lynne Zarbatany, and Wendy Ellis. 2018. Social Sensitivity and Social, School, and Psychological Adjustment among Children across Contexts. Developmental Psychology 54: 1124. [CrossRef] [PubMed]

Chmielecki, Michał, and Łukasz Sułkowski. 2018. Cultural Factors of Trust in a Public Organization as a Workplace. In Managing Public Trust. Edited by Barbara Kożuch, Sławomir J. Magala and Joanna Paliszkiewicz. Cham: Palgrave Macillan, pp. 99-115.

Choma, Becky L., Reeshma Haji, Gordon Hodson, and Mark Hoffarth. 2016. Avoiding Cultural Contamination: Intergroup Disgust Sensitivity and Religious Identification as Predictors of Interfaith Threat, Faith-based Policies, and Islamophobia. Personality and Individual Differences 95: 50-55. [CrossRef]

Christens, Brian D., and Tom Dolan. 2011. Interweaving Youth Development, Community Development, and Social Change through Youth Organizing. Youth E Society 43: 528-48.

Crouch, Harold. 1979. Patrimonialism and Military Rule in Indonesia. World Politics 31: 571-87. [CrossRef]

Danaj, Adela, Kornélia Lazányi, and Yuriy Bilan. 2018. Perceptions and Implications of Immigration in France-Economic, Social, Political and Cultural Perspectives. Economics and Sociology 11: 226-47. [CrossRef] 
de Jong, Edwin, and Argo Twikromo. 2017. Friction within Harmony: Everyday Dynamics and the Negotiation of Diversity in Yogyakarta, Indonesia. Journal of Southeast Asian Studies 48: 71-90. [CrossRef]

Demircioglu, Serife, and Cemal Cakir. 2016. Intercultural Competence of Students in International Baccalaureate World Schools in Turkey and Abroad. International Education Studies 9: 1-14. [CrossRef]

Diprose, Rachael, Dave McRae, and Vedi R. Hadiz. 2019. Two Decades of Reformasi in Indonesia: Its Illiberal Turn. Journal of Contemporary Asia 49: 691-712. [CrossRef]

Dong, Qingwen, Kenneth D. Day, and Christine M. Collaço. 2008. Overcoming Ethnocentrism through Developing Intercultural Communication Sensitivity and Multiculturalism. Human Communication 11: 27-38.

Dugan, Kate. 2007. Buddhist Women and Interfaith Work in the United States. Buddhist-Christian Studies 27: 31-50. [CrossRef]

Feillard, Andree. 1999. NU vis a vis Negara; Pencarian Isi, Bentuk dan Makna. Jakarta: LKiS Pelangi Aksara.

Fritz, Wolfgang, Antje Mollenberg, and Guo-Ming Chen. 2001. Measuring Intercultural Sensitivity in Different Cultural Context. Paper presented at Biannual Meeting of the International Association for Intercultural Communication Studies, Hong Kong, China, 24-29 July 2001.

Gebregeorgis, Mehari Yimulaw. 2017. Peace Values in language Textbooks: The Case of English for Ethiopia Student Textbook. Journal of Peace Education 14: 54-68. [CrossRef]

Geertz, Clifford. 1976. The Religion of Java. Chicago: University of Chicago Press.

Greenholtz, Joe F. 2005. Does Intercultural Sensitivity Cross Cultures? Validity Issues in Porting Instruments across Languages and Cultures. International Journal of Intercultural Relations 29: 73-89. [CrossRef]

Griffith, Richard L., Leah Wolfeld, Brigitte K. Armon, Joseph Rios, and Ou Lydia Liu. 2016. Assessing Intercultural Competence in Higher Education: Existing Research and Future Directions. ETS Research Report Series 2: 1-44. [CrossRef]

Grigaitytė, Ingrida, Karin Österman, and Kaj Björkqvist. 2019. Proactive Attitudes towards Integration and Intense Group Identification, in a Sample of the Swedish-Speaking Minority of Western Finland. European Journal of Social Science Education and Research 6: 23-36.

Hamayotsu, Kikue. 2013. The Limits of Civil Society in Democratic Indonesia: Media Freedom and Religious Intolerance. Journal of Contemporary Asia 43: 658-77. [CrossRef]

Hammer, Mitchell R., and Milton J. Bennett. 1998. The Intercultural Development Inventory (IDI) Manual. Portland: Intercultural Communication Institute.

Hammer, Mitchell R., Milton Bennett, and Richard Wiseman. 2003. Measuring Intercultural Sensitivity: The Intercultural Development Inventory. International Journal of Intercultural Relations 27: 421-43. [CrossRef]

Haugen, Hans Morten. 2017. Faith among Youths in Church of Norway Means Greater Interreligious Acceptance. Nordic Journal of Religion and Society 30: 97-114. [CrossRef]

Hefner, Robert W. 1993. Islam, State, and civil Society: ICMI and the Struggle for the Indonesian Middle Class. Indonesia 56: 1-35. [CrossRef]

Hefner, Robert W. 2011. Civil Islam: Muslims and Democratization in Indonesia. Princeton: Princeton University Press, 40 vols.

Hefner, Robert W. 2013. The Study of Religious Freedom in Indonesia. The Review of Faith E International Affairs 11: $18-27$.

Hefner, Robert W. 2018. A Muslim Civil Society? Indonesian Reflections on the Conditions of Its Possibility 1. In Democratic Civility. Edited by Robert w. Hefner. New York: Routledge, pp. 285-322.

Hefner, Robert W. 2019. Whatever Happened to Civil Islam? Islam and Democratisation in Indonesia, 20 Years on. Asian Studies Review 43: 375-96. [CrossRef]

Holm, Kristiina, Petri Nokelainen, and Kirsi Tirri. 2009. Intercultural and Religious Sensitivity of Finnish Lutheran 7th to 9th Grade Student. In Religious Diversity and Education: Nordic Perspectives. Edited by Geir Skeie. Münster: Waxmann Verlag GmbH, 11 vols. pp. 131-44.

Holm, Kristiina, Elina Kuusisto, and Inkeri Rissanen. 2019. Intercultural and Interreligious Sensitivities in a Finnish Educational Context. In Contextualising Dialogue, Secularisation and Pluralism: Religion in Finnish Public Education. Edited by Martin Ubani, Inkeri Rissanen and Saila Poulter. Münster: Waxmann Verlag $\mathrm{GmbH}, 40$ vols. pp. 183-202.

Hunt, Robert. 2009. Can Muslims Engage in Interreligious Dialogue? A Study of Malay Muslim Identity in Contemporary Malaysia. The Muslim World 99: 581-607. [CrossRef] 
Ipgrave, Julia, and Ursula McKenna. 2008. Diverse Experiences and Common Vision: English Students' Perspectives on Religion and Religious Education. In Encountering Religious Pluralism in School and Society: A Qualitative Study of Teenage Perspectives in Europe. Edited by Thorsten Knauth. Münster: Waxmann Verlag $\mathrm{GmbH}, 5$ vols. pp. 113-47.

Jakobsh, Doris R. 2006. Sikhism, Interfaith Dialogue, and Women: Transformation and Identity. Journal of Contemporary Religion 21: 183-99. [CrossRef]

Jonathan, Andreas, Paulus Widjaja, and Fatimah Husein. 2018. Fostering Religious Exclusivism and Political Pluralism in Indonesia Through Interfaith-based Student Community. KnE Social Sciences 3: 53-70. [CrossRef]

Jones, Sidney, Elga Sarapung, Jeremy Menchik, Mohammed Najib Azca, Sana Jaffrey, Titik Firawati, and Zainal Abidin Bagir. 2015. Sisi Gelap Demokrasi: Kekerasan Masyarakat Madani di Indonesia. Jakarta: Centre for the Study of Islam and Democracy.

Kadayifci-Orellana, S. Ayse. 2013. Inter-Religious Dialogue and Peacebuilding. In The Wiley-Blackwell Companion to Inter-Religious Dialogue. Edited by Catherine Cornille. Hoboken: Wiley-Blackwell, pp. 149-67.

Kadir, Suzaina. 1999. The Islamic Factor in Indonesia's Political Transition. Asian Journal of Political Science 7: 1-44. [CrossRef]

Kimanen, Anuleena, and Elina Kuusisto. 2017. How Young People Perceive Factors that Support or Prevent Understanding between Worldviews: Perspectives of Finnish Lower Secondary School Pupils. Intercultural Education 28: 75-89. [CrossRef]

Knauth, Thorsten. 2007. Religious Education in Germany: Contribution to Dialogue or Source of Conflict? In Religion and Education in Europe: Developments, Contexts and Debates. Edited by Robert Jackson, Siebren Miedema, Wolfarm Weisse and Jean-Paul Williame. Münster: Waxmann Verlag GmbH, 3 vols. pp. 243-65.

Kollar, Nathan R. 2016. The Interfaith Movement in a Liminal Age: The Institutionalization of a Movement. Journal of Ecumenical Studies 51: 7-30. [CrossRef]

Kuusisto, Arniika, Elina Kuusisto, Kristiina Holm, and Kirsi Tirri. 2014. Gender Variance in Interreligious Sensitivity among Finnish Pupils. International Journal of Children's Spirituality 19: 25-44. [CrossRef]

Kuusisto, Elina, Arniika Kuusisto, and Arto Kallioniemi. 2016. How is Interreligious Sensitivity Related to Finnish Pupils' Religiousness Profiles? British Journal of Religious Education 38: 64-82. [CrossRef]

Larson, Marion, and Sara Shady. 2009. Interfaith Dialogue in a Pluralistic World: Insights from Martin Buber and Miroslav Volf. Journal of College and Character 10: 1-9. [CrossRef]

Latif, Yudi. 2011. Negara Paripurna: Historis, Rasionalitas, dan Aktualitas Pancasila. Jakarta: PT. Gramedia Pustaka Utama.

Liebmann, Louise Lund. 2017. Interfaith Dialogue in Christian Norway: Enactment of Inclusive Religiosity as Civilized Behavior. Journal of Religion in Europe 10: 301-27. [CrossRef]

Lüthi, Lorenz. 2014. The non-Aligned: Apart from and Still within the Cold War. In The Non-Aligned Movement and the Cold War. Edited by Natasa Miskovic, Harald Fischer-Tiné and Nada Boskovska. New York: Routledge, pp. 115-31.

McKenna, Ursula, Sean Neill, and Robert Jackson. 2009. Personal Worldviews, Dialogue and Tolerance: Students' Views on Religious Education in England. In Teenagers' Perspectives on the Role of Religion in Their Lives, Schools and Societies: A European Quantitative Study. Edited by Pille Valk, Gerdien Bertram-Troost, Markus Friederici and Céline Béraud. Münster: Waxmann Verlag GmbH, 7 vols. pp. 49-70.

Michaelides, Pavlos E. 2009. Interfaith Dialogue in Global Perspective and the Necessity of Youth Involvement. Asia Europe Journal 7: 449. [CrossRef]

Miedema, Siebren. 2014. From Religious Education to Worldview Education and Beyond: The Strength of a Transformative Pedagogical Paradigm. Journal for the Study of Religion 27: 82-103.

Mulder, J. A. Niels. 1970. Aliran Kebatinan as an Expression of the Javanese Worldview. Journal of Southeast Asian Studies 1: 105-14. [CrossRef]

Muwahidah, Siti. 2008. Interfaith Dialogue at the Grassroots Level: A Case Study of an Interfaith Empowerment Program in East Java, Indonesia. Political Theology 9: 79-92. [CrossRef]

Nakamura, Mitsuo. 2012. The Crescent Arises Over the Banyan Tree: A Study of the Muhammadiyah Movement in a Central Javanese Town, c. 1910-2010. Singapore: Institute of Southeast Asian Studies.

Nielson, Jorgen S. 2002. The Contribution of Interfaith Dialogue toward a Culture of Peace. American Journal of Islamic Social Sciences 19: 103-8. 
Abu-Nimer, Mohammed. 2001. Conflict Resolution, Culture, and Religion: Toward a Training Model of Interreligious Peacebuilding. Journal of Peace Research 38: 685-704. [CrossRef]

Obar, Jonathan A. Paul Zube, and Clifford Lampe. 2012. Advocacy 2.0: An Analysis of How Advocacy Groups in the United States Perceive and Use Social Media as Tools for Facilitating Civic Engagement and Collective Action. Journal of information policy 2: 1-25. [CrossRef]

Paffenholz, Thania, ed. 2010. Civil Society \& Peacebuilding: A Critical Assessment. Boulder: Lynne Rienner.

Park, Jae Bong. 2012. Managing Socio-Economic Crisis in Indonesia: The Role of Interfaith Civic Organisations in Yogyakarta during the 1998 Economic Crisis. Indonesia and the Malay World 40: 39-58. [CrossRef]

Patel, Eboo. 2006. Affirming Identity, Achieving Pluralism: Sociological Insights from a () Practitioner of Interfaith Youth Work. In Building the Interfaith Youth Movement: Beyond Dialogue to Action. Edited by Eboo Patel and Patrice Brodeur. Lanham: Rowman \& Littlefield Publisher Inc., pp. 15-24.

Patrick, Margaretta L. 2015. A Call for More Religious Education in the Secondary Social Studies Curriculum of Western Canadian Provinces. Curriculum Inquiry 45: 154-75. [CrossRef]

Pedersen, Kusumita P. 2004. The Interfaith Movement: An Incomplete Assessment. Journal of Ecumenical Studies 41: 74-94.

Petrović, Danijela S., Jelena Starčević, Guo-Ming Chen, and Darko Komnenić. 2015. Intercultural Sensitivity Scale: Proposal for a Modified Serbian Version. Psihologija 48: 199-212. [CrossRef]

Power, Thomas P. 2018. Jokowi's Authoritarian Turn and Indonesia's Democratic Decline. Bulletin of Indonesian Economic Studies 54: 307-38. [CrossRef]

Puett, Tiffany. 2005. On Transforming Our World: Critical Pedagogy for Interfaith Education. CrossCurrents 55: 264-73.

Putnam, Robert D. 1994. Social Capital and Public Affairs. Bulletin of the American Academy of Arts and Sciences 47: 5-19. [CrossRef]

Riddell, Peter G. 2002. The diverse voices of political Islam in post-Suharto Indonesia. Islam and Christian-Muslim Relations 13: 65-84. [CrossRef]

Rissanen, Inkeri, Elina Kuusisto, and Arniika Kuusisto. 2016. Developing Teachers' Intercultural Sensitivity: Case study on a Pilot Course in Finnish Teacher Education. Teaching and Teacher Education 59: 446-56. [CrossRef]

Rokhmad, Abu, and Sulistiyono Susilo. 2017. Conceptualizing Authority of the Legalization of Indonesian Women's Rights in Islamic Family Law. Journal of Indonesian Islam 11: 489-508. [CrossRef]

Sarapung, Elga, and Corrie van der Ven. 2016. From Religion as Part of the Problem to Religion as Part of the Solution: Case Study on Multi-religious Engagement for Peace and Conflict Solution in Indonesia. The Ecumenical Review 68: 433-43. [CrossRef]

Schulze, Kirsten E. 2017. The "ethnic" in Indonesia's Communal Conflicts: Violence in Ambon, Poso, and Sambas. Ethnic and racial studies 40: 2096-114. [CrossRef]

Seda, Francisia S. S. E., Lugina Setyawati, Yosef Hilarius Timu Pera, and Rika Febriani. 2018. Social Policies, Social Exclusion \& Social Well-Being in Southeast Asia: A Case Study of Papua, Indonesia. Economics and Sociology 11: $147-60$.

Sezgin, Yüksel, and Mirjam Künkler. 2014. Regulation of "Religion" and the "Religious": The Politics of Judicialization and Bureaucratization in India and Indonesia. Comparative Studies in Society and History 56: 448-78. [CrossRef]

Shabir, Muslich, and Sulistiyono Susilo. 2018. Muhammad Abduh's thought on Muhammadiyah Educational Modernism: Tracing the Influence in Its Early Development. Qudus International Journal of Islamic Studies 6: 127-60. [CrossRef]

Shehada, Nahda. 2009. Flexibility versus Rigidity in the Practice of Islamic Family Law. PoLAR: Political and Legal Anthropology Review 32: 28-46. [CrossRef]

Simionescu, Mihaela, Yuriy Bilan, Luboš Smrčka, and Zuzana Vincúrová. 2017. The Effects of European Economic Integration and the Impact of Brexit on the UK Immigrants from the CEE Countries. E $+M$ Ekonomie a Management 20: 29-47. [CrossRef]

Smith, Jane I. 2007. Muslims, Christians, and the Challenge of Interfaith Dialogue. Oxford: Oxford University Press. Strielkowski, Wadim, Yuriy Bilan, and Oleh Demkiv. 2016. Religion and International Migration: A Case Study of Ukraine. Religions 7: 64. [CrossRef] 
Sułkowski, Łukasz. 2017. Social Capital, Trust and Intercultural Interactions. In Intercultural Interactions in the Multicultural Workplace. Edited by Małgorzata Rozkwitalska, Łukasz Sułkowski and Slawomir J. Magala. Cham: Springer, pp. 155-71.

Sunarko Ofm, Adrianus. 2016. Interfaith dialogue and cooperation across faiths: The experience of Indonesia. Theology Today 73: 46-59. [CrossRef]

Susilo, Sulistiyono, and Reza Pahlevi Dalimunthe. 2019. Moderate Southeast Asian Islamic Education as a Parent Culture in Deradicalization: Urgencies, Strategies, and Challenges. Religions 10: 45. [CrossRef]

Tamam, Ezhar. 2010. Examining Chen and Starosta's Model of Intercultural Sensitivity in a Multiracial Collectivistic Country. Journal of Intercultural Communication Research 39: 173-83. [CrossRef]

Tamam, Ezhar, and Steven Eric Krauss. 2017. Ethnic-related Diversity Engagement Differences in Intercultural Sensitivity among Malaysian Undergraduate Students. International Journal of Adolescence and Youth 22: 137-50. [CrossRef]

van Bruinessen, Martin. 1994. Pesantren and Kitab Kuning: Continuity and Change in a Tradition of Religious Learning. Bern: University of Bern.

van Bruinessen, Martin. 1996. Islamic State or State Islam? Fifty Years of State-Islam Relations in Indonesia. In Indonesien am Ende des 20. Jahrhunderts. Edited by Ingrid Wessel. Hanburg: Abera-Varlag, pp. 19-34.

Wang, Wenting, and Mingming Zhou. 2016. Validation of the Short form of the Intercultural Sensitivity Scale (ISS-15). International Journal of Intercultural Relations 55: 1-7. [CrossRef]

Ward, Ken. 2010. Soeharto's Javanese Pancasila. In Soeharto's New Order and Its Legacy: Essays in Honour of Harold Crouch. Edited by Edward Aspinall and Greg Fealy. Canberra: The Australian National University, 1 vols. pp. 27-38.

Wu, Jia-Fen. 2015. Examining Chen and Starosta's Model of Intercultural Sensitivity in the Taiwanese Cultural Context. International Journal of Modern Education and Computer Science 7: 1. [CrossRef]

Yilmaz, Ihsan, and James Barry. 2018. Instrumentalizing Islam in a 'Secular' State: Turkey's Diyanet and Interfaith Dialogue. Journal of Balkan and Near Eastern Studies, 1-16. [CrossRef]

Yuen, Celeste Y. M., and David L. Grossman. 2009. The Intercultural Sensitivity of Student Teachers in Three Cities. Compare 39: 349-65. [CrossRef]

Yukich, Grace, and Ruth Braunstein. 2014. Encounters at the Religious Edge: Variation in Religious Expression across Interfaith Advocacy and Social Movement Settings. Journal for the Scientific Study of Religion 53: 791-807. [CrossRef]

Yurtseven, Nihal, and Sertel Altun. 2015. Intercultural Sensitivity in Today's Global Classes: Teacher Candidates' Perceptions. Journal of Ethnic and Cultural Studies 2: 49-54. [CrossRef] 